\title{
Anthropology at the University of Yaounde I: A Historical Overview, 1962-2008
}

\author{
Paul Nchoji Nkwi* \& Antoine Socpa**
}

\begin{abstract}
The teaching of anthropology at the University of Yaoundé I dates back to the very birth of the university, even though, the word anthropology was not used explicitly. The rapid growth of the discipline was enhanced by the 1993/94 university reforms which offered a window of opportunity to the discipline to redefine itself and rehabilitate its image after decades of battering. From a few students in the 1980s, the discipline enrolls over a hundred students every year at Yaoundé. The increased numbers and importance of the discipline led to the creation of separate department of anthropology with a strong faculty capable of teaching and awarding degrees at all levels.
\end{abstract}

\section{Résumé}

L'enseignement de l'Anthropologie à l'Université de Yaoundé I prend naissance à partir de la date de création de l'Université, bien que le mot Anthropologie ne fut pas explicitement utilisé. La croissance ou le développement rapide de la discipline est mise en valeur à partir de la réforme universitaire de 1993/1994 qui a ouvert la fenêtre des opportunités à cette discipline afin de se redéfinir elle-même et réhabiliter son image après des décennies de mauvais traitement. Avec peu d'étudiants vers les années 1980, la discipline inscrit des milliers d'étudiants à l'Université de Yaoundé. Le nombre croissant des étudiants et l'importance de la discipline a pour conséquence, la

* Department of Anthropology - University of Yaoundé I. Email: nchoji@yahoo.com.

** Department of Anthropology - University of Yaoundé I.

Email: asocpa@yahoo.com. 
création d'un département séparé de l'anthropologie avec une grande faculté capable d'enseigner et de délivrer les diplômes à tous les niveaux.

\section{Introduction}

The teaching of anthropology at the University of Yaoundé dates back to the creation of this institution. Its status and existence today as an autonomous discipline within the Cameroon university system is the result of a long struggle. It is therefore, important to discuss the history, in order to grasp the motives and the context that favoured the reforms and changes, and which, subsequently, affected the teaching of anthropology at this university. The University has undergone a number of reforms since its creation in 1962, but the most significant changes are those of January 1993 which provide a niche for anthropology as a strategic discipline within the university system.

Anthropology began timidly at the University of Yaoundé through the teaching of basic courses on the Family, Marriage, Kinship and other related topics between 1962 to 1980s. It gained greater importance in the 1990s as more and more teachers and students were recruited. This paper looks at the events that have shaped anthropology in this context, and the impact of recent reforms on other emerging universities in the country

Anthropology as the study of humankind, is defined and taught in a variety of ways. On continental Europe, anthropology referred more to the study of the genetically inherited characteristics of humankind while ethnology as the study of contemporary cultures was given more prominence. In the Americas, anthropology includes physical and cultural anthropology. While physical anthropology focuses on the genetically inherited characteristics of man (palaeontology, comparative human biology, comparative primatology, etc), cultural anthropology looks at the socially learned behaviour of humankind (ethnology, archeology, linguistics).

What is taught at the University of Yaoundé I is cultural anthropology which tend to follow the American traditions of the four fields. This trend dates back to late 1970s when Paul Nchoji Nkwi was recruited as an assistant professor. Before then, ethnology was being taught given that the founding fathers of Cameroon anthropology were trained in France. The fundamental change in the late 1970s was largely determined by the huge amount of literature coming out of the American tradition. For the past two decades, culture as a fundamental concept has been at the basis of anthropology. Even though some early anthropologists looked at culture as a sum total of ideas and behaviour shared 
by a group, Durkheim and Goodenough (1970) approach culture from a cognitive perspective and defines it as a sum total of representations, ideas and symbols shared by members of a society. The word anthropology, used in this paper, refers to cultural anthropology.

\section{The Establishment and Growth of the University of Yaoundé}

By a presidential decree 9 of July 1962 (no. 62-DF-28), the Federal University of Cameroon was created which will later become the University of Yaoundé in 1972 and the University of Yaoundé I in 1993. The creation brought to an end a long and fierce debate on the necessity of such an institution. In the 1950s, the Trusteeship Council of United Nations had proposed the creation of an institution of higher learning in Cameroon. When the recommendation was submitted to the conference of Directors of Education in Black Africa, they rejected the idea as "utopic". The institution was established to meet the standards and quality of European universities.

The conference instead proposed a University college to train African middle-level manpower without "metropolitan grades" (Marchand, 1962). France, the administrator of one section of the Trusteeship territory of Cameroon, was by that fact required to submit every year a report on the social, economic and political situation in the trusteeship territory. Even though the League of Nations was pushing for a university, France considered the number of candidates for Bachelor Degree holders insufficient to justify the creation of such an institution. Instead, France promised to increase the number of higher education scholarships for studies abroad (cf. Bulletin de L'Inspection Générale de l'Enseignement et de la Jeunesse, Ministère de la France d'outre-mer, Juillet 1950, p.15). France also believed that the crucial problem was the training of local administrative officers. Officers trained in foreign universities in Europe were not at all adapted to the needs, if not, to the specific realities of the colony.

Furthermore, most Cameroonians trained abroad did not return. In addition, the number of officers required, was far higher than those being produced in foreign institutions. They could not satisfy the long term needs, given the limited scholarships and the up-keep of students constituted a heavy financial burden on both bilateral and international assistance. The necessity to train more local senior officers adapted to the needs of the country, and to slow down brain drain, necessitated the creation of a number of institutions of higher learning in the colonies. For Cameroon, the attempt to develop such institutions led finally to the 
creation of The National Institute for University Studies in Cameroon (decree DC/61-55 of April 25 1961). The Institute funded mostly by France provided two years of university studies in Law ("capacité") to holders of at least the General Certificate of Education, controlled by the University of Toulouse. With the assistance of France steps were taken to provide the teaching staff and the necessary funds for the creation and management of the University.

For the Federal University of Cameroon to become functional, the French Foundation for Higher Education was established to run the various institutions. In 1962, the new university comprised of the following institutions: the Higher Teachers' Training School (ENS) sponsored by UNESCO, The Faculty of Law and Economic Sciences, The Faculty of Letters and Human Sciences and the Federal School of Agriculture supported by FAO. The Faculty of Sciences was established a year later in 1963. Six years later, two other institutions were created, namely, the Centre for the Management of Enterprise and the University Centre for Health Sciences (CUSS).

Created as a National Institute for University Studies in 1962, the Federal University which later on became the University of Yaoundé (1970-1971) has witnessed a remarkable demographic and infrastructural development. The different University institutions operated in different parts of the city of Yaoundé. By the beginning of the academic year 1967/ 68 , all the faculties moved into their own campuses constructed in NgoaEkelle. France's financial and material support was critical for the development of the University, thanks to a special agreement between Cameroon and France, giving France complete control of higher education for a period of 10 years. The teaching staff was recruited under this special agreement and most of the staff were French nationals or Cameroonians paid by the French. In 1972 a presidential decree nationalised the university and France was forced to withdraw its hold on the system. Some Cameroonian staff, previously paid by France refused to accept local salaries and went on strike. When a new decree signed in October 1976 increased substantially the salaries of teachers, slowed down brain drain and enhanced the teaching profession.

With the growing numbers of students, problems of infrastructure, professionalisation, and in keeping with the policy of regional balance decree no. 77/108 of April 281977 raised the existing university institutions into four new university centers, namely :

- Douala, the University Centre for Sciences and Business.

- Buea, University Centre for Languages and Letters. 
- Dschang, University Centre for Agronomic Sciences.

- Ngaoundere, University Centre for Science and Technology.

However, the creation of these Centres was designed to slow down the exponential growth of the student population at the University of Yaoundé because the centres limited the numbers of students admitted to each centre.

It must be noted that the Federal University had a student population of 3334 in 1972 when Cameroon took it over from the French. The numbers continued to grow without the expansion of infrastructure (see Table1).

Table 1: Admission from 1962-1992 at the University of Yaounde

\begin{tabular}{lcc}
\hline Year & No. of students & Percentage growth \\
\hline $1961 / 1962$ & 213 & \\
$1971 / 1972$ & 3334 & $29 \%$ \\
$1981 / 1982$ & 15800 & $8 \%$ \\
$1991 / 1992$ & 51000 & $12 \%$ \\
\hline
\end{tabular}

Despite the creation of professional university centres, the number of students at the campus of the University of Yaoundé continued to swell while these universities institutions remained empty. The state was obliged to create six universities by decree no. 93/026 of January 19, 1993. We will come back to these reforms later on, for these had a great impact on the emerging importance of anthropology in these new universities. ${ }^{1}$

It is must be stated clearly that the state was reluctant to giving full expression to Anglo-Saxon culture. Although English and French were the official languages of the University, very few French-speaking teachers bother to master the English language. The converse was not true with English speaking staff. English speaking students found it difficult to express themselves in French or French constituted an additional burden on them. When they went to the street to demand an Anglo-Saxon University, it was readily given when the Prime Minister went on Radio and Television, and told the students that such a university would be created. It is against this background that the University of Yaoundé split up into Yaoundé I and Yaoundé II and three other Universities were created in Dschang, Ngaoundere, Buea, and Douala. 


\section{The Status of Anthropology before the 1993 Reform}

Right from the creation of the University some anthropology courses were taught in the Faculty of Letters and Human Sciences. The decree creating the Federal University in 1962 stipulates in article 11 that the Faculty of Letters and Human Sciences would award Bachelor Degrees in Letters to students who had successfully passed the examinations leading to the award of - five certificates of higher Education - that made up the Bachelor's degree. The following degrees were to be awarded:

1- Classical Letters,

2- Modern Letters,

3- History and Geography,

4- Human Sciences (Philosophy),

5- Human Sciences (Sociology),

6- Human Sciences (Psychology).

In order to be awarded a degree in Sociology, the student was required to have obtained the Certificate of Ethnology. The degree in Human Sciences (Sociology) was composed of the following certificates:

1- Certificate of History of Civilisations,

2- Certificate in general Sociology,

3- Certificate in general Psychology,

4- Certificate in Ethnology,

5- Certificate in Political and Social Economy.

Designed along the French University system, Ethnology was taught as sub-discipline of social sciences. All students taking sociology were required to take courses in ethnology. Although a separate department in anthropology did not exist, studying ethnology was a vital component of the degree in Human Sciences (Sociology). From the beginning there were conscious efforts to bring anthropology on board right in the early years of the Federal University of Cameroon. The following course were taught:

\section{History and Methodology}

- The major theories in sociology (ethnology),

- Definition of Sociology and Social Sciences,

- Sociology and Psychoanalysis,

- Sociological Research, methods \& techniques of research on the field,

- Ethnology and Sociology, signification of archaism. 


\section{Sociological Problems}

- The levels of interpretation of social phenomena;

- Typology of groups; social morphology;

- Sociology of language;

- The types of family organisations;

- Social control and political sociology.

\section{Electives}

- Economic Sociology and Sociology of work,

- African Ethnology.

The reforms of 1980s merged the three degrees in human sciences into a degree in Philosophy. The reforms proposed the removal of sociology and anthropology entirely from the teaching programme, a move that met stiff resistance from both sociologists and anthropologists whose action led to the creation of a full department of Sociology within which the two disciplines were taught. Indeed, these reforms permitted students to take common courses in both philosophy and sociology during the first two years. It was in the third year that they specialised in sociology, but graduating with a combined degree in philosophy/sociology. The courses offered in ethnology were reduced considerably to a single course entitled the Sociology of Traditional Africa. Students interested in anthropology could only take courses in the third year with the possibility of studying anthropology at the graduate level -(fourth-fifth years).

Here is a sample of the common courses in philosophy-sociology:

\section{First Year}

- Social Science History,

- Methods of research in social sciences,

- Initiationinto anthropology,

- Introductiontostatistics.

\section{Second Year}

- Social Sciences History,

- Methods of research in social sciences,

- Social psychology,

- Statistics,

- Anthropology of the family,

- Sociology of development. 


\section{Third Year}

Common Courses:

- Sociology of the deviance,

- Sociology of work,

- Demography,

- Methods of research in social sciences,

- People and cultures of Cameroon,

- People and cultures of the world,

- Methods of analysis and interpretation of sociological texts,

- General Anthropology.

\section{Social Structures}

- Women and Development,

- Urban Anthropology,

- Applied Anthropology,

- Anthropology of development,

- Religious anthropology.

Sociology: Electives

- Sociology of Development,

- Urban Sociology,

- Political Sociology,

- Sociology of education,

- Sociology of population.

Although students graduating with degrees in Philosophy-Sociology had basic notions in anthropology, it is interesting to note that the staff was predominantly anthropologists.

\section{Profile of Staff of the Department of Sociology}

Although anthropology was not taught in all its various forms and given the prominence it deserved, the presence of the discipline was visible in the people who taught and administered the department of sociology. When the department was established in the 1960s, it was a French anthropologist who was chair and for the next 12 years, the department would remain in the hands of anthropologist. By 1986, there were 12 members of staff in the department of Sociology of which 7 were anthropologists. By 1993 when the discipline was given a full autonomous status (granting degrees: B.Sc, Master, Ph.D), there were 12 anthropologists on the teaching staff. 
At no time were there more sociologists than anthropologists in the department. Throughout the 1980s, there were 12 members of staff, 7(52\%) were anthropologists while 5(48\%) were sociologists. Furthermore, some anthropologists prefer to be labelled as sociologists.

Historically, anthropology in France and the rest of Europe meant physical anthropology while social and cultural anthropology was seen as part of sociology or ethnology. The role played by anthropology during the colonial period created a difficult climate for the discipline. Having served as a handmaiden of colonialism, anthropology was seen and described by African intellectuals, academics and nationalists as a colonial discipline that had nothing to do with the new emerging and modernising process of Africa. Even though great names like Busia and Kenyatta became political leaders in their respective countries, that fact did not enhance the discipline as a strategic subject for Africa's development. Consequently, many Africans who studied anthropology or ethnology in North American and European Universities returned to a University system that was hostile to the discipline. Carrying the label sociologist was more acceptable and marketable than the label anthropologist. Many who studied anthropology did so within the context of cultural renaissance, carving a niche for Africa within world history. The struggles of Cheik Anta Diop and other African scholars to restore the dignity of African cultures became a great inspiration to those who went on to study anthropology despite the hostility.

In 1986 virtually, all staff members were trained abroad. Only two had been entirely trained in Cameroon. The rest were trained in the USA, France, Switzerland, Germany and Belgium and came from a variety of professional backgrounds and experiences. This was a great asset to the department. Again, they came back to a university system with little incentives for research and teaching. The lack of resources further exasperated the situation and played negatively on their careers. Their professional careers seemed to stagnate once they became senior lecturers. For the entire history of the department, no sociologist has ever risen to the rank of full professor. The promotion system which requires quality publications and professional performance made it impossible for most teachers to move to higher ranks. This made it very difficult the training of students at the graduate level. Indeed, moving to higher grades, required the completion of academic training with a PhD or Doctorat d'État. Teachers with Doctorat $3^{\mathrm{e}}$ cycle were required to obtain the Doctorat d'État before they could seek promotion to the rank of associate professor. Teachers who studied in the German system were also required to 
obtain Habilitation before applying for promotion while those with Ph.Ds from the USA and Great Britain could evolved professionally without further restrictions provided they fulfilled the requirements of publications.

Although, the teachers of anthropology came from a variety of University backgrounds, yet the teaching of the discipline at the University of Yaoundé was strongly based on the American anthropology tradition. However, archaeology and linguistics are taught in separate departments. What came to be know as anthropology at the University of Yaoundé I was basically cultural anthropology with a strong focus on the applied dimensions which emerged as part of the new reforms of 1993.

\section{The 1993 University Reform}

The 1993 reforms were preceded by a debate in the Ministry of Higher Education about the employability potentials of the entire teaching programme at the lone University of Yaoundé. The need to provide students with skills and experience would provide solutions to the unemployment crisis. Each discipline was required to brainstorm on the possibility of reforming the University system with emphasis on capacity building and skills acquisitions.

The growing number of students was posing a serious infrastructural problem. Built in the late 1960s to accommodate 10,000 students, the same infrastructure was handling over 50,000 students by 1991/92 academic year. In order to deal with these numbers, five new Universities were created out of the University of Yaoundé: Yaoundé II (Soa), Douala, Dschang, Ngaoundere and Buea. The old University of Yaoundé became University of Yaoundé I.

In the old University system, admissions were limited to students 25 years of age. But with the reform, all qualified Cameroonians wishing to pursue University education could register in these institutions as stipulated by article 2 of decree no. 93/027 of January 1993. These guidelines offered a unique occasion for anthropology to redefine its vision and mission within the new university reforms.

Although some courses in anthropology were taught in the department of sociology, the department was not known as the department of sociology and anthropology. With the reforms, a department of sociology and anthropology was established raising anthropology to the status of a first degree awarding discipline. Before the reforms, students could only obtain masters and doctorate degrees in anthropology but not first degrees. The 1993 reforms introduced a first degree (B.A) programme and made admissions into the master degree fairly flexible and liberal. All students with first degree were allowed to enrol directly into 
a master degree programme. This measure was designed to hold back the students for another year. It was only the PhD programme that imposed a rigorous selection process.

Inspired by government's desire to professionalise the disciplines, the new courses in anthropology were redesigned to permit students to acquire basic notions of applicability and practice. Table 2 shows the different courses, designed, debated by teachers of anthropology and approved by the university senate and council.

Table 2: Courses in Anthropology after the Reforms of 1993

\begin{tabular}{|c|c|}
\hline Code Level & Course Title \\
\hline UV 111 & Introduction to General Anthropology \\
\hline UV 112 & History of Anthropology \\
\hline UV 113 & Social Structure and Organisation \\
\hline UV 114 & Material Culture: Technology,. \\
\hline UV 115 & Introduction to Ethnographic Research: \\
\hline UV 116 & Introduction to Ethnolinguistics \\
\hline UV 117 & Concept of Culture And Civilisation \\
\hline UV 118 & Introduction to Systems of Belief \\
\hline UV 119 & Bilingual Training \\
\hline UV 120 & Introduction to Cultural Anthropology \\
\hline UV 121 & The Anthropology of African Family \\
\hline UV 122 & TheAnthropology of the Supernatural \\
\hline Code Level & Course Title \\
\hline UV 211 & Current Theories In Anthropology \\
\hline UV 212 & Introduction to Physical Anthropology \\
\hline UV 213 & Culture and Personnality \\
\hline UV 214 & Cultural Dynamics \\
\hline UV 215 & Peoples and Cultures of Cameroon \\
\hline UV 216 & Political and Legal Anthropology \\
\hline UV 217 & Bilingual Training \\
\hline UV 221 & Systemic Analysis ( Marriage And Family) \\
\hline UV 222 & Medical and Nutritional Anthropology \\
\hline UV 223 & Urban Anthropology \\
\hline UV 224 & Anthropology of Development \\
\hline Code Level & Course Title \\
\hline UV 311 & $\begin{array}{l}\text { Fieldwork Techniques And Methods (Quantitative } \\
\text { And Qualitative) }\end{array}$ \\
\hline UV 312 & Material Culture ( Economic) \\
\hline
\end{tabular}


UV 313

UV 314

UV 315

UV 316

UV 317

UV 321

UV 322

UV 323

UV 324

Code Level

UV 4111

UV 4112

UV 4113

UV 4211

UV 4212

UV 4213

UV 4214

UV 4311

UV 4312

UV 4313

UV 4314

UV 4411

UV 4412

UV 4413

UV 4414

Code Level

UV 5111

UV 5112

UV 5113

UV 5211

UV 5212

UV 5213

UV 5214

UV 5311

UV 5312

UV 5313

UV 5314
Peoples And Cultures of Africa

Peoples And Cultures of The World

Linguistic Anthropology

Anthropology of Religion

Bilingual Training

Systemic Analysis

Medical Anthropology

Anthropology of Development

Urban Anthropology

\section{Course Title}

Advanced Training In Research Methods

Fieldwork and Computer Applications

Seminar

P olitical and Legal Anthropology

Family and Kinship Systems

Social Organisationn and Social Inequalities

Anthropology of Religion

Population Issues and Reproductive Health

International Health and Anthropology

Cultural Perceptions of Illness and Disease

Social Science and Health

Urban Anthropology : Theory and Praxis

Community Development and Sustainability

Environmental Anthropology : Social Impact

Assessment

Taxonomies \& Systems of Semantic Relationships

\section{Course Title}

Advanced Training In Research Methods

Fieldwork and Computer Applications

Seminar

Social Organisation and Differenciation

The African Family in Transition

Social Transformation of Kinship Structure

Traditional Authority in Transitions

Primary Health Dialectics : Programmes and

Evaluation

Reproductive Health \& New Approaches to

Population Issues

Public Health Policies and Praxis

Alternative Medicine: Traditional Healing Practices 


\section{The Profiles of Students}

The enrolment of students was timid during the first years of the reform but gathered momentum at all level in the years following. The reforms had given an additional impetus. During the 1993/94 academic year only 10 students enrolled in anthropology. In 1994/95, the number rose to 18 and by 1995/96, there were 23 students. Table 3 shows the number of students from the 1993 reforms to 2008. The significant increase comes in 1996/97 academic year when the numbers rose to 32 and in 1997/98 there were 121 students studying anthropology at all levels (first degree, masters and $\mathrm{PhD}$ ). By 1998/99 academic year, the total number had risen to 182.

Between 1993/94 and 1997/98, a total of 204 students studied at the level of first degree, masters and $\mathrm{PhD}$ and $90(44 \%)$ of the 204 were women while $114(56 \%)$ were men. When one takes a look at the enrolment between 1996/97 and 2006/2007, the increased enrolment of young women is significant, and most of them come from diverse professional backgrounds including nursing, education, environment, journalism and other civil profession.

Table 3: Progressive Admissions of Students 1996-2008

\begin{tabular}{lrrc}
\hline Year & Total & Girls & Boys \\
\hline $1996 / 97$ & 32 & 11 & 20 \\
$1997 / 98$ & 121 & 75 & 46 \\
$1998 / 99$ & 182 & 101 & 81 \\
$1999 / 2000$ & 465 & 190 & 275 \\
$2000 / 2001$ & 554 & 229 & 325 \\
$2001 / 2002$ & 320 & 140 & 180 \\
$2002 / 2003$ & 582 & 259 & 323 \\
$2003 / 2004$ & 411 & 203 & 208 \\
$2004 / 2005$ & 393 & 222 & 171 \\
$2005 / 2006$ & 474 & 254 & 220 \\
$2006 / 2007$ & 533 & 273 & 260 \\
$2007 / 2008$ & 340 & 173 & 167 \\
\hline
\end{tabular}

In the late 1970s and 1980s, government imposed an age limit to admissions by making anyone above the age of 25 illegible. This measure was directed against civil servants who pursued degree courses while working. With the economic crisis looming and unemployment rising, the 1993 university reforms opened the doors of the university to all qualified irrespective of age. A new category of students ${ }^{2}$ student-workers emerged and progressively increased. Statistics obtained from the admission of- 
fice show that between 1993/94 and 1998/99 a total of 386 students enrolled in anthropology and $150(39 \%)$ of them are workers.

\section{Graduates in Anthropology and the University of Yaoundé I}

Before the university reforms, specialisation in anthropology was limited to Masters and PhD degree programmes. On the whole after the Masters degree, many students went abroad to continue their studies. Few students pursue PhD degrees at Yaoundé. The staff actively encouraged student to seek higher degrees abroad where conditions for research were conducive and better. Library resources and research opportunities hardly existed at Yaoundé. Encouraging students to study aboard was designed to create greater exposure and prepare them for a more active professional life. As a consequence, none completed their $\mathrm{PhD}$ at Yaoundé. Several bachelor and masters degrees in anthropology were awarded to over 52 students between 1993 and 1999. Table 4 is a synthesis of areas of specialisation in anthropology and sociology.

Table 4: Number of Students in the Different Specialisation between 1993-1999

\begin{tabular}{lcc}
\hline Specialisation & Number by specialisation & Percentage (\%) \\
\hline Anthropology & 52 & 25 \\
Sociology & 159 & 75 \\
Total & $\mathbf{2 1 1}$ & $\mathbf{1 0 0}$ \\
\hline
\end{tabular}

Graph 1: Ratio of specialisations in anthropology and Sociology

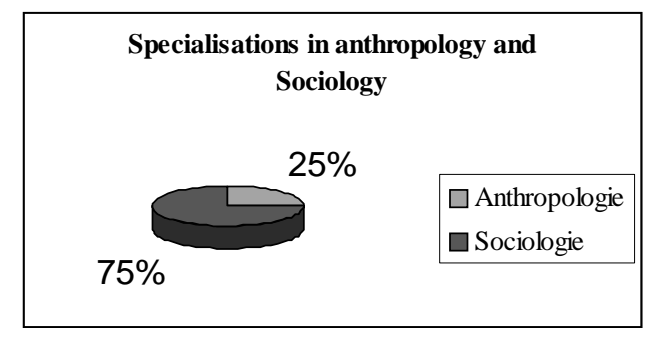

The Graphic theses and dissertations covered a wide range of themes and specialisation, but the emerging trend was the focus applied areas. This was largely due to the nature of the teaching programme which emphasised the acquisition of skills and practical experience. 
However, cultural and social Anthropology constituted privileged domains of research. Out of 52 anthropological dissertations presented at the university of Yaoundé 1 over the last 25 years, 14 (28\%) handled issues in cultural anthropology whereas $10(20 \%)$ dealt with issues in social anthropology. 10 of the 52 dissertations were in medical anthropology, 6 in ethnolinguistics, 4 in political anthropology and religion and the rest in archaeology, anthropology of development, environmental anthropology and economic anthropology.

The university reforms led to the creation of the department of sociology and anthropology. From 1993-94 to 2008, the department awarded degrees in anthropology and sociology and the two disciplines functioned as one administratively, but each awarded BA, Masters and PhD separately. In 2008, the ministry of Higher education, based on the demographics (over 650 students) and a qualified teaching staff of almost 10 (two professors, 6 senior lecturers, 3 assistant lecturers), created a separate department of anthropology. The new department has challenges of a different nature and its determination to meet these challenges shows up in the efforts to recruit more and more qualified staff and engaged in more research.

\section{Future Perspectives}

The establishment of the first African universities was designed to provide qualified manpower for the newly independent nation-states. For example, a country in Central Africa had only sixteen university graduates at the time of independence and twelve of these were priests. Between 1960 and 1970, university graduates found easily employment in the civil service. Even those who obtained degrees in anthropology were easily employed in the various ministries. Unemployment of was not a problem, given that professional schools such the National School of Public Administration (ENAM) recruited its students largely from secondary schools with GCE O \& A levels rather from the university system. Only the school of Magistracy recruited students with law degree.

By the end of 1970s and beginning of the 1980s, the civil service was saturated with a critical mass of university graduates and it began to absorb graduates selectively through a competitive process. Those who could not make it floated in the labour markets. By 1986, the employability of university graduates significantly diminished. When President Biya signed a decree authorising the Public service to recruit 1500 university graduates, many found employment in the public service with little or no substantive work load. With the structural adjustment pro- 
gramme of the 1980s placing several restrictions on recruitments, the state was forced to scale down on further recruitments.

The university reforms of the early 1990s were aimed at producing graduates with practical skills that would generate self-employment. The reforms regrouped sister-disciplines with the aim of providing broad base education in order to enhance their performance as teachers. Major combined degrees such as History-Geography and Philosophy-Sociology were designed to produce teachers for the secondary schools. A few courses in anthropology were taught in the new combined degree of Philosophy-Sociology. Philosophy was being a teaching subject in secondary schools, not anthropology or sociology. Anthropologist with a combined degree could teach basic courses in philosophy. Indeed, students who graduated with a combined degree in philosophy-sociology went on to pursue higher studies in anthropology, but ended up as secondary school teachers.

The reforms only provided ephemeral solution to a growing problem of unemployment. By the end of the 1980s, the teaching field was saturated to such an extent that the state called on universities to design the teaching programmes to produce graduates with self-employment skills. Efforts at professionalisation sought to provide vital practical skills to provide self-employment.

For anthropology, the question was "how could anthropology offer vital and critical survival skills to students. Already, the collapse of the modernisation theory in 1960s had generated a whole new debate about alternative answers to development questions. This debate opened a new window of opportunity to anthropology. The anthropological insights and its micro-analytic perspective were being explored as alternative routes to the development. Would anthropology offer the answers? How could anthropology respond to the increased demands of development agencies?

In response to these questions, the design of anthropology programmes at the University of Yaoundé tried to address these concerns. The classical training in anthropology was overhauled in the light of new demands, that is, training students with vital survival skills. The university, a world of ideas and idealism or a market place of ideas, was open to the demands of the world of actions, policy and practices (Nkwi, 2006). While our colleagues in North America and Europe were asserting that applied anthropology was not anthropology, those of us who taught and reacted with the world of action believed that anthropology can only be meaningful and useful if it listens to the daily voices of developers bringing 
induced change to communities. Academic anthropology was indeed inextricably linked to development anthropology. Furthermore, for anthropology to rehabilitate the colonial image in Africa, it had to use its insights to address myriads of problems facing the social transformation of the continent.

Experience has shown that more and more anthropologists are being called upon by international Organisations and NGOs to assist them bring induced change to many rural communities. In Cameroon alone, government, intergovernmental agencies, international NGOs, such as GTZ, DED, IUCN, SNV, AFVP, APFT, CARE, UNESCO, UNICEF, and many others use the services and expertise of anthropologists. The challenge to those training students of culture was to prepare them for a world that is seeking alternatives to sustainable development practice. Could anthropology offer some alternatives? The new teaching programmes responded to this concern.

Consequently, the anthropology programme at the University of Yaounde focused on applied issues right from the first year after the reforms. While theoretical training was essential and considered important, the practical training aimed at providing professional skills that would transform students into culture-brokers for development and consultants for organisations that sought their expertise. The training was tailored to the demands of the end-users: government, national and international organisations. The applied areas include medical and health issues, development issues, systemic analysis, urban development and problems related environment.

\section{Which Way Forward?}

The future of anthropology in the decades ahead will depend on how anthropology addresses the challenges of the $21^{\text {st }}$ century. One of the major challenges is meeting the needs and demands of a fast changing world. The rehabilitation of its image is well on the way to full recovery but the integration of anthropological insights into the development process of African nations must become a permanent and not just an ephemeral feature. The 1990s opened a window of opportunity and only quality research and training will maintain the stakes open. While action-research is critically important for policy-makers, the work of applied anthropologists must feed into the teaching programmes within the academy.

If anthropology in Yaoundé has witnessed a significant increase in students, this has been largely due to the dream that anthropology as an applied discipline can offer employment in the private and public sec- 
tors that are increasingly looking to anthropologists for answers. To do this, teaching programmes must address theoretical, conceptual as well as practical need that meet the employability.

Indeed, anthropology can only gain respectability among the social sciences if its performance as an applied discipline meets the standards. Such an achievement will depend on a commitment to solid training in theory and practice. The survival of anthropology will also depend on its capacity to transcend micro-analytic approach to a more interdisciplinary and transdisciplinary comprehension and adaptation. The more students are trained in comparative multi-disciplinary methodology, the more will they be armed to work with others whose knowledge and comprehension of anthropological insights is either limited or prejudiced. Anthropologists must learn to work in multidisciplinary teams for today and tomorrow's development problems are no more an affair of one discipline, but the concern of all. It is only in doing so can the discipline assert its position as a strategic discipline within the development equation.

The case of anthropology at the University of Yaoundé I, serves as a model for many of our sister universities in Africa. There is increasing number of people from other disciplines taking anthropology as a degree subject. Over the last five years, the university has admitted matured students (teachers, journalists, nurses, and civil administrators). The training of this new crop of students will certainly develop a new advocacy and marketing of the discipline beyond its frontiers. As our students are getting into some liberal professions such as army, police, private entrepreneurship, there is hope that this will create a niche for the discipline in the future.

The employment of our students by Non-Governmental Organisation (NGOs) to perform a variety of duties opens another window of opportunity for the discipline. As NGOs are increasingly involved in grassroots development activities, the more they will continue to need anthropological insights. If the training is adapted to the applied needs of development organisations, the more will the academy enhance its role and place within the development equation. It has been said that the lost decades of Africa's development has been due to the neglect of the micro-analytic approach, it is our hope that anthropology will provide the much needed insights that will make a difference

In the age of globalisation, Africa is faced with the dilemma of handling cultural invasion and the revival of African cultural values. Many nation-states will have to deal ultimately with the difficulties of strad- 
dling between the African and foreign cultures, borrowing what is essential and retaining what is beneficial. Africa's renaissance will depend on Africa's capacity to deal with the invading cultures whose technological advantage will minimise Africa's values and norms. If African nations are to preserve cultural values and norms now and in the future, they must invest in strengthening and in the employability of anthropology students. The recent reforms in Cameroon which have permitted anthropology to develop into a full fledged discipline are commendable.

\section{Notes}

1. Statistic for Table 1 from 1993 academic year to 2008 could not be found due to the absence of reliable and credible data from the registration office of the University.

2. On Table 3 the figure for $2000 / 2001$ is arrived at without student enrolled in level 4 and 5 and the figure for 2001/2002 have only enrollment figures for level 3 and 4 only.

\section{References}

\section{A. Books}

Beals, R., \& Hoijer, H., 1965, An Introduction to Anthropology, New York : The McMillan Co.

De Haas, M.1994, Anthropology, Dept of Anthropology, University of Natal.

Ekambi, M.J., \& Saïbou, N., 1993, Répertoires des mémoires et thèses en Sociologie et anthropologie, in Annales de la Faculté des Lettres et Sciences Humaines, Université de Yaoundé.

Faculté des Lettres et Sciences Humaines, 1978, Livret de l'Etudiant, 19781979, Yaoundé.

Goodenough, W.P., 1970, Description and comparaison in cultural Anthropology, Chicago: Adline Publishing Co.

Keesing, R., 1981, Cultural Anthropology: A contemporary Perspective. New York: Holt, Rinehart and Winston.

Kekedi, N.R., 1979, The Students of Yaoundé University, Dissertation for the Masters, University of Yaoundé, 137p.

Marchand, C., 1962, La scolarisation française au Cameroun, ORSTOM.

Ministère de la France Outre-Mer,1950, Bulletin de l'inspection Générale de l'enseignement et de la jeunesse, juillet.

Nkwi, P., 2006, "Anthropology in a Postcolonial Africa: The survival debate" in World_Anthropologies, Disciplinary Transformation within Systems of Power, by Gustavo Lins Ribeiro and Arturo Escobar (eds), Berg Publications, Oxford, New York, pp. 157-180.

Republic of Cameroon, 1974, Council for higher education and scientific and technical research, Yaoundé. 
Republic of Cameroon, 1982, Act of Higher Education and Scientific and Technical Research, Yaoundé, 158p.

Republic of Cameroon, 1993, University Reform of Cameroon, Yaoundé, 351p. The University of Yaoundé, 1978, Student Handbook, 1978-1979, 61p.

\section{Decrees}

Decree no. 67/df/566 of 28/12/67 putting an end to the transitional period of the Federal University of Cameroon and modifying decree no. 62/dfl of $26 \mathrm{July}, \mathrm{p}$. 38-58.

Decree no. 69/df/504 of 21/11/69 modifying decree no. 67/df/566 of 28/12/67 putting an end to the transitional period of the creating of the Federal University of Cameroon.

Decree no. 69/df/380 of 17/09/69 organising the second cycle of the Faculty of Letters and Human Sciences of the Federal University of Cameroon.

Decree no. 71/284 of 15/6/71 creating the Africanist Research Centre(CRA) within the Federal University.

Decree no. $79 / 186$ of 17/5/79 fixing the amount and means of payment of University fees.

Decree no. 82/83 of 19/2/82 fixing the roles of organisation, the functioning and the control of students associations in the Faculty of big schools. 


\section{Annexes}

\section{A. Listing of work done on Anthropology}

\section{Cultural Anthropology: 14 thesis and dissertations}

(i) Essono Aloo, E., 1975, Une Institution socioculturelle chez les Ntumu l'Aba, BU, Mémoire de DES, U.Y.

(ii) Negha, J., 1976, L'ascencion dans la société traditionnelle : Etude de la chefferie de Bansoa en pays Bamileke (Ouest-Cameroun), B.U., Mémoire de DES, UY

(iii) Miaffo, D., 1977, Rôle social de l'autopsie publique traditionnelle, Mémoire de DES, UY

(iv) Nzikam Djomo, E., 1977, Les rites relatifs à la naissance chez les Fe'e de Babouantou ( $p$ antu), mémoire de DES, UY.

(v) Sihaka C., 1978, La mort Bamileke : Essai sur l'enterrement chez les Bayangam, mémoire de DES, UY.

(vi) Ayuk, B.P.,1979, Banyang Socio-Cosmological Beliefs and Institutions in the process of change, mémoire de DES, UY.

(vii) Kegne Jean, 1978, Contribution à l'étude du fondement du dynamisme Bamileke (étude anthropologique), mémoire de DES, UY.

(viii) Onana Badiang, 1979, Les jumeaux chez les Yambassa. Rites et croyances relatifs au phénomène gémellaire chez les Bugunu, mémoire de DES, UY.

(ix) Nshom Sama, C., 1981, Contribution of anthropology to development. A case study of the Bamendjin Clan and its Socio-cultural Impact on Bambalang, mémoire de maîtrise, U.Y

(x) Mbonji, 1983, Les jeux et leurs fonctions sociales en Afrique Noire. L'exemple des jeux Douala, thèse de doctorat $3^{\mathrm{e}}$ cycle, UY

(xi) Nouck, Bassomb, 1984, Le mythe de la restauration chez les Bassa du SudCameroun, mémoire de maîtrise, UY

(xii) Abega, S.C.,1984, L'Esana des Beti du Sud-Cameroun, thèse de doctorat $3^{\text {e }}$ cycle, UY

(xiii) Tchouyou, P., 1986, Les fondements socio-culturels des associations d'étudiants originaires d'une même région au Cameroun, mémoire de maîtrise, UY

2. Medical Anthropology: 9 thesis and dissertations

(i) Mbock II Y., 1978, Procréation et médecine en Afrique Noire: Essai sur la thérapeutique traditionnelle de la stérilité et de l'accouchement chez les Bassa du Sud Cameroun, mémoire de DES, UY.

(ii) Tiokou Ndonko, F., 1987, Représentations culturelles de l'épilepsie chez les Bamileke: le cas de Maham, mémoire de maîtrise, UY.

(iii) Socpa, A., 1995, Les pharmacies de rue dans l'espace médical urbain au Cameroun. Emergence et déterminants des stratégies informelles d'accès au médicaments a Douala, thèse de $3^{\mathrm{e}}$ cycle, UY1.

(iv) Messina, C.B., 1999, Représentations socio-culturelles du goitre chez les Maka: le cas de Bend, mémoire de maîtrise, UY1.

(v) Ngambouck, V., 1999, The Growth of urban traditional medicine: A case study of street pharmacy vendors in Yaounde, mémoire de maîtrise , UY. 
(vi) Tatah, P., 1997, The future of medicinal plants, mémoire de maîtrise UY1.

(vii) Angu, K., 1997, The consumption of palm oil and vitamin A deciency disorders among the Mokunda people, South-West province of Cameroon, Mémoire de maîtrise, UY1.

(viii) Ndzana, B., 1999, Le rôle du coq et de la poule dans les rites thérapeutiques traditionnels chez les Manguissa, mémoire de maîtrise

(ix) Tantchou, J., 1999, Prise en charge des enfants prématurés en milieu non hospitalier : le cas des Bamileke, mémoire de maîtrise, UY 1

3. Social Anthropology: 10 thesis and dissertations

(i) Onambele, Marie-José, 1978, La structure clanique des Ewondo, mémoire de DES, UY

(ii) Amougou, B., 1979, La parenté chez les Fong face à la civilisation moderne, mémoire de DES, UY.

(iii) Ntsama C., 1979, Le veuvage de la femme dans la tradition Bamileke: Essai sur les rites de viduité chez les Bafou, mémoire de DES, UY

(iv) Mba, D., 1981, La société PIH chez les Bamileke de l'Ouest du Cameroun. Le cas du groupe Ngemba, mémoire de maîtrise, UY

(v) Ngima Mawoung, G., 1981, L'intégration des pygmées dans la société camerounaise. Le cas du secteur Bipindi dans le département de l'Océan, mémoire de maîtrise, UY.

(vi) Nshom Sama, C., 1981, Contribution of anthropology to development. A case study of the Bamendjin clan and its socio-cultural impact on Bambalang, mémoire de maîtrise, UY

(vii) Onguene Mgba, P., 1981, Anthropologie sociale et développement rural au Cameroun, mémoire de maitrise, UY

(viii) Miaffo, D., 1984, Mutation du travail et ses représentations chez les Bulu du Sud-Cameroun, Thèse de $3^{\text {e }}$ cycle UY

(ix) Mebenga Tamba, L.,1990, Les funérailles chez les Ewondo, Thèse de $3^{e}$ cycle, UY1

(x) Neh Scholastica, 1990, Polygyny in an urban context. The case of Bamenda urban area (North-West Province), mémoire de maîtrise, UY

(xi) Socpa, A., 1990, Les camps de regroupement dans la chefferie de Babadjou (Ouest-Cameroun) 1960-1976, mémoire de maîtrise UY.

\section{Archeology: 1 Thesis}

(i) Mebenga Tamba, L., 1981, Qui habitait les terrasses de la plaine du Ndop ? Etude archéologique des sites en terrasses, mémoire se maîtrise

\section{Ethnolinguistics: 6 thesis and dissertations}

(i) Tchoupa, P., 1975, Education traditionnelle chez les Bamileke à partir de quelques contes, mémoire de DES. 
(ii) Tchuade A., 1986, Anthroponymie et organisation sociale chez les Nkwe'nzhi (Ouest-Cameroun), approche ethnolinguistique, mémoire de maîtrise

(iii) Chili Abdou, 1987, La notion du temps chez les Bamoun, mémoire de maîtrise, UY.

(iv) Njoya Oumarou, 1988, Théorie bamun de la parole (Ouest-Cameroun), mémoire de maîtrise, UY

(v) Ndongo, L. A., 1991, Dénomination et symbole des couleurs chez les Beti (Cameroun Central), mémoire de maîtrise, UY1.

(vi) Balla, C., 1991, Parole et pouvoir chez les Beti (Cameroun Central), mémoire de maîtrise, UY1.

6. Anthropology of religion: 2 thesis and dissertations

(i) Fontem Shu, J., 1975, Religious conflict in Bafut, mémoire de DES, UY

(ii) Soh Bejeng P., 1975, A study of Lela, a Bali-Tchamba state cult of the NorthWest Graasfields of Cameroon, B.U, mémoire de DES, UY

\section{Political Anthropology: 4 thesis and dissertations}

(i) Che Fombong, W., 1977, The council of notables and the French colonial Administration in Cameroon. An-evaluative study, mémoire de DES, UY

(ii) Ebassola Ada, 1979, Organisation politique traditionnelle des Boulou, B.U, Mémoire de DES, UY

(iii) Ngwayi Sonde A., Kwame, 1987, The Wimbum elite and the Nfuh traditional institution, mémoire de maîtrise, UY

8. Anthropology of development: 2 Thesis

(i) Kiawi, E., 1990, Development Associations and socio-economic Development. The case of Kom. Mémoire de maîtrise, UY1.

(ii) Attia Ndze, J., 1990, The problems of rural development agencies : the case of Wum Area Development

9. Economic Anthropology: 2 thesis and dissertations

(i) Judy Lyengu Luma, 1990, A socio-cultural Analysis of the Informal food service sector. An urban anthropological case study of road side food stands and chicken parlours in Yaounde, mémoire, UY1.

(ii) Ngo Likeng, J., 1999, L'ethnologie d'une activité féminine de développement : la pêche aux crevettes dans la région de Lobe-Kribi, Mémoire de maîtrise, UY1.

10. Environmental Anthropology: 1 thesis

(i) Akwa, Neba, G., 1999, Gestion traditionnelle de la forêt chez les Baka, Bagando. Mémoire de maîtrise, UY1. 


\section{B. Table of Specialisations in Anthropology}

\begin{tabular}{llll}
\hline Specialisation & $\begin{array}{c}\text { Number by specialisation } \\
\text { Percentage (\%) }\end{array}$ & Total Number \\
\hline Cultural Anthropology & 14 & 52 & 27 \\
Political Anthropology & 4 & 52 & 8 \\
Anthropology of religion & 2 & 52 & 4 \\
Ethnolinguistics & 6 & 52 & 12 \\
Archeology & 1 & 52 & 2 \\
Social Anthropology & 11 & 52 & 21 \\
Anthropology of development & 2 & 52 & 4 \\
Environmental Anthropology & 1 & 52 & 2 \\
Economical Anthropology & 2 & 52 & 4 \\
Medical Anthropology & 10 & 52 & 19 \\
\hline
\end{tabular}

